\title{
'Honor' Killings in Misogynistic Society: A Feminist Perspective
}

\author{
Abdul Hadi \\ Assistant Professor, \\ Department of Sociology, \\ Faculty of Arts and Sciences, \\ Harran University, Turkey
}

Doi: 10.36941/ajis-2020-0039

\begin{abstract}
The plight of women in Pakistan is terrible in terms of gender-based violence. Every year more than thousand women have been killed in the name of 'honor'. The aim of this paper is to explain the underlying causes of the incidents of 'honor' killings, and find out the reason why many instances of 'honor' killings go unreported and the perpetrators usually able to evade punishment. This study found that the prevailing ideology of honor, a stimulus to honor killing, gender-biased, abusive, and corrupt to the core police force along with the weak judicial system and legal loopholes in existing laws are the determining factor of unabated incidents of killing under the pretext of honor. This study asserts that Pakistani government must act quickly and decisively to plug legal loopholes in order to halt the most consistent, abhorrent heinous violence from going unpunished. Furthermore, the gender bias permeates in institutions at all levels, therefore, there must be mandatory sensitivity training for both the police investigating honor crimes and the judges adjudicating over them. The authorities must ensure that police without bowing to any pressure be it political or religious impartially investigate the cases of 'honor' killings. This study understands that the incidents of honor killings are the manifestation of the patriarchy, therefore, aforementioned measures are critical elements but not sufficient to deal the issue of 'honor' killing. There is the need of transformative change in society which can occur with the reduction of gender inequality. The state of women cannot be improved unless women get economic independence, greater access to education, increase participation in political activities, and get widespread awareness of socio-economic and political issues.
\end{abstract}

Keywords: Honor killing, Patriarchy, Gender-based Violence, Pakistan, Honor Codes

\section{Introduction}

Gender-based violence persists across cultures affecting all women irrespective of their social standing. They experience various forms of violence such as physical, sexual, psychological, and emotional violence. Though the violence committed on women is not a new phenomenon, it was explicitly acknowledged by the international community the first time in 1993 in the Declaration on the Elimination of violence against women adopted by (UN) General Assembly.

This declaration defines the term violence against women as:

any act of gender-based violence that results in, or is likely to result in, physical, sexual or psychological harm or suffering to women, including threats of such acts, coercion or arbitrary deprivation of liberty, whether occurring in public or private life. (United Nations General Assembly, 1993). 
Violence against women continues to remain a serious problem across the world. Women experience rape, 'honor' killings, sexual harassment, intimate partner violence, and sexual harassment to name a few. Out of the multiple forms of violence inflicted on women, "honor" killing is at the top of the list. It is a worst form of VAW that implies that a victim has transgressed to the socially acceptable behavior, broken the code of "honor" and brought shame on the family, and hence become an offense liable for punishment ranging from physical, social, and psychological violence to the killing of a person who transgressed the code of conduct. Both men and women have been witnessed to be the victims of "honor" killing; however, in general, women get killed in these matter because of being dependent and controlled by their family fail to find either refuge or help to escape. Conversely, men often escape to a safe haven or are forgiven or made to pay compensation in cash or in the form of the hand of relative women in marriage.

"Honor" killing is not a recent phenomenon; such crimes in the name of 'honor' have been happening throughout history all over the world in many communities, countries, and cultures. There was the belief in the codes of Hammurabi, Nesilim, and Assura, that a husband was entitled to murder his unfaithful wife and her paramour (Goldstein, 2002). Similarly, in ancient Rome, fathers had the right to kill their daughters on their 'dishonorable' behavior and upon their daughter's marriage, which right was transferred to their husbands. The Roman political leader Marcus Cato stated once, "If you catch your wife in adultery, you can kill her with impunity; she, however, cannot dare to lay a finger on you if you commit adultery, for it is the law" (Goldstein, 2002). In medieval Europe, early Jewish law mandated death by stoning for an adulterous wife and her partner (Cantarella, 1991; cited in Shoro, 2019). The killing unfaithful wife for protection and restoration of family's 'honor' was legally sanctioned in the Germanic tribes of Western Europe, the Chinese, Japanese, and other Asian cultures (Daly and Wilson, 1988). The historical account of the 'honor' related crimes confirms that the killing in the name of 'honor' with legislative backing is neither a new phenomenon nor limited to any specific part of the world.

The submitted reports to United Nations Commission on Human Rights disclose that killing under the pretext of 'honor' occurs in countries including Bangladesh, Great Britain, Brazil, Ecuador, Egypt, India, Israel, Italy, Jordan, Pakistan, Morocco, Sweden, Turkey, and Uganda. Even the incidents of 'honor' killings have been reported in the US and Canada (Amnesty International USA, 2012). Every year thousands of women are killed in the name of 'honor'; a however significant number of these incidents go unreported which makes it impossible to have verifiable statistical data of victims. The United Nations Population Fund put estimation that every year nearly 5000 women and girls are killed under the pretext of 'honor' around the world (United Nations Population Fund, 200o). The number of victims is 4 times higher in the estimation of many women's groups belonging to the Middle East and South-West Asia which give the figure of around 20,00o (Fisk, 2010). Although cases of 'honor' killing have been reported all around the world, South Asia and Middle East regions are hotspots (Bhanbhro, 2015). In the South Asian region, Pakistan is infamous for VAW, and 'honor' killing has become an increasingly common practice.

Pakistan has been in the news for the frequent cases of "honor" killing occurrences. The recent annual report of Human Rights Watch (2019) estimates that there are about 1,ooo 'honor' killings every year. The statistics on 'honor' killing are difficult to obtain and are often inaccurate due to under-reporting of such incidents. The main reason for underreporting of these crimes is unwillingness of victims' family members to come forward. One of the evils of the practice of 'honor' killing is that it has become a business since the notion of 'honor' is used as a cover for other killings. The inquiries of some reported incidents of 'honor' killings disclosed a trumped-up charge that hid the real causes behind these killings such as obtaining land, financial gains, property disputes, greed over the issue of inheritance, and family or tribal rivalry. The aim of this paper is to analyze the statistical data of the 'honor' killing crimes over the last two decades and explain the determining factor behind the occurrence of these crimes. The main aim of this study is to find out the effect of new-'honor' law introduced in 2016 on the frequency of 'honor' killing incidents.

This study presents a brief introduction to the social context of Pakistan, followed by statistical 
data of 'honor' killings in Pakistan over the last two decades and then there is a discussion about the motivating factors of this practice and what measures should be taken to eliminate it.

\section{Social Context of Pakistan}

Pakistan is the Federal Republic, which comprises four provinces with a population of over 216 million. All of the provinces have their own distinctive cultures; underneath these cultures, there are a number of sub-cultures, which each have their own different moral and traditional values. The Pakistani community is divided into urban and rural classes; the urban population is much more privileged than the rural population. In general, Pakistani society is a patriarchal society wherein patriarchy determines the subordinated status of women to men. Patriarchy is both structural and ideological. It is structural because it bears on the access of women to institutions and their position in it. The patriarchal system is premised on power relations, which are hierarchical and unequal wherein men hold sway in production, reproduction, and sexuality of women. This control has been established and legitimized by social institutions like family, religion, media, and society. It is ideological as it not only reproduces and perpetuates society's beliefs, norms, and values about women's role and status in society, but also controls women through institutionalized restrictive codes of conduct, segregation of both genders and through the association of family 'honor' to the virtue of women.

In Pakistani communities, 'honor' (Urdu: izzat) is highly valued and it is in the conduct, actions, and social performances of women that families attain 'honor' and prestige. As izzat ('honor') relies on the behavior of women, safeguarding the family izzat ('honor') can also be viewed as a means of exercising social control over women's bodies and behavior (Gill 2009). The concept of 'honor' makes male family members responsible for regulating and guarding not only the moral and sexual behavior of their female family members but also their dress codes and social conduct. Wikan (2008) asserts that people who value 'honor' are not only motivated to attain and retain 'honor' but also concerned with avoiding shame; 'honor' is associated with conduct expected of individuals of a particular community, while shame is linked with the transgressions against these expectations (Gill, 2014). In general, 'honor' and shame have different practical implications for both genders. 'honor' code concerning to men, who are viewed as the safeguard of family's social standing, centers around the well-being of their families, maintenance of their authority over the families, and their virility. While, 'honor' code concerning to women revolves around sexual shame which entails the restraint in the expression of sexual behavior such as staying virgin before marriage, modesty, decorum in dress, and a sense of shame in their social relations with men. The conduct and reputation of women in the family in terms of sexual shame is the most important determinant of the status of family honor. Lacking of sexual shame on the part of women in the family is a significant antecedent for the loss of the family 'honor' thereby caring for women's sexual conduct become the main concern of the men of the family to protect the family's 'honor'. As women are conceived as the repository of family's 'honor', their movements and patterns of behavior are directed by close men relatives whether it be a father, husband, or a brother.

Another highly valued concept in Pakistani society is manhood. Manhood refers to the attributes, characteristics and gendered roles of being a man. Men gain 'honor's through exerting their dominance and control over family's women and lose 'honor's when they fail to exert dominance and control over them, whereas women preserve their 'honor' through their subordinacy, obedience, chastity, endurance and virginity, and they may lose it through an autonomous act, particularly those concerning to sexuality (Arun Pal, 2012, as cited in Sharma, 2016). A woman behaving honorably in a family indicates that men being the guardian of the family have kept them under control and well protected and that the men's domination in the family has been well established. Women who do not behave in an honorable way show that men of the family have not only failed to control and protect their women but also have failed to defend the 'honor' of their family (Kordvani,2002), which can be seen as a threat to their masculinity/manhood. Any Pakistani 
who has a sense of 'honor' is more concerned with the issue of his reputation and fears of losing value and respect before others' eyes. His familial respect, social prestige and the notion of 'honor' determine his position and status in the society; women of his family are perceived as the vessel of family's 'honor', thereby defending the chastity of women under their dominance and protection is the key concern for men of the family. Having experienced shame and loss of face due to the dishonor'able behavior of women of the family, men must punish them to prove their masculinity and restore the 'honor' of the family else, they and their family may be labeled as 'dishonored family' families without 'honor'.

In the patriarchal society where codes of honor prevail and manhood is highly valued, the significant influences on women's lives are education, class differences, the rural/urban division, tribal and feudal norms, and uneven socio-economic conditions. For example, the women live in the cities enjoy better work opportunities, education, and freedom than those who live in rural villages. Except for a few influential, elite groups of women, the social set-up begins with unwritten slavery for women and ends abruptly at the authoritative attitude of men (Shoro, 2019). This is the reason that Pakistan has been ranked the second-worst country in terms of gender equality in the world by the Global Gender Gap Index 2018, flanked by Iraq (147) and Yemen (149). The scores are based on economic participation and opportunity, educational attainment, health and survival, and political empowerment (Human Rights Commission of Pakistan, 2019).

Gender inequality and gender-based marginalization make women vulnerable to violence, which is reported to be on the rise in Pakistan. Violence against women includes rape, intimate partner violence, forced marriages, sexual harassment, child marriage, 'honor' killings, acid attacks, and abuse in police custody. According to Thomson Reuters Foundation Annual Poll 2018, Pakistan has been ranked as the sixth most dangerous country for women and fourth among the worst nation where women face risks from cultural, religious, and traditional practices including killing in the name of 'honor'. It also has been ranked fifth when it came to non-sexual violence including domestic abuse, and joint seventh regarding sexual violence and harassment.

\section{Statistical Data of 'Honor' Killing in Pakistan}

After the creation of Pakistan to the late 1980s, there was no terminology such as 'killing in the name of 'honor" or "honor' killing' known or used by the common people. For the last four decades, the rising number of 'honor' killings has been primarily interlinked with changes in the secular law of Pakistan introduced by the military regime of the dictator General Zia-ul- Haq (Shoro, 2019). Today, the number of incidents of 'honor' killings is higher in Pakistan, both reported and unreported. The VAW and 'honor'-based crimes are rampant across the country, occurring in all classes, ethnic and religious groups, and regions. Although both men and women are witnessed to be the victims of 'honor' killings. Men usually escape to a safe haven or are forgiven or made to pay compensation in cash or in the form of the hand of relative women in marriage. While, women being dependent and controlled by their family, fails to find either refuge or help and get killed and often their corpses are thrown into rivers or buried in unknown graveyards without giving a proper burial.

Across Pakistan, hundreds of women of all ages are murdered in the name of 'honor'. This study went through the compiled data of 'honor' murders given in well-reputed organizations such as the Human Rights Commission of Pakistan of the last two decades to observe the pattern of the occurrences of "honor" killing incidents. Since 2001, according to Pakistan's Interior Ministry of Pakistan, more than 4,100 women were murdered under the pretext of 'honor' (Human Rights Watch, 2007) and this crime continued to rise in 2007 (Human Rights Commission of Pakistan, 2008) and remain a serious problem along with other gender-based violence. Instead of taking incidents seriously, the attitudes of politicians in Pakistan appear to be apathetic and defending it in the name of culture. In 2008, when five women have been shot and buried alive for marrying against the wishes of their families, a senator from the respective province justified this 'honor' crime as "tribal custom" (Human Rights Watch, 2009). The gender-biased and outdated mindset that perceives women as the 
vessel of family's 'honor' permeates even among the officers of law enforcement agencies that often involves in protecting the perpetrators. On April 3, 2009, a girl, third-year student at college, developed an acquaintance with a man from a different tribe, was strangled to death by her close family members in the name of 'honor'. The Deputy Superintendent of Police, a relative of the victim's girl, gave orders to the local authorities to hush up the case (Human Rights Commission of Pakistan, 2010). More than 1,400 women suffered the same fate in the name of protection and restoration of 'honor' within two years 2009 and 2010 (HRCP, 2010; 2010). The incidences of 'honor' killing continued in the following years. The annual reports of the Human Rights Commission of Pakistan $(2013$; 2014; 2015) revealed that in three years more than 2,800 women fell prey to "honor" killing. The same trend of the incidents of 'honor' murders continued in the following years. HRCP (2017) estimated that hundreds of women and girls suffered the same fate in the name of protection and restoration of the family's 'honor'.

The increasing reports of 'honor' killings, few of them highly mediatized, along with the campaign and struggle of women rights activists put pressure on the government of Pakistan to make amendments in laws so that offenders cannot evade punishment and that may deter would-be offenders. As a result, in October 2016, an anti-'honor' killing bill was passed to eliminate this most persistent, abhorrent violence inflicted on women and girls. This bill mandates life imprisonment or the death penalty for convicted murderers, whose motive for the killing was supposed restoration of 'honor' and strips families of the right to pardon the offenders of 'honor' killings, a practice that allowed the perpetrators to evade punishment under Qisas (retribution) and Diyat (blood money) laws. There were high hopes with the passing of the law and it was anticipated that Qisas and Diyat laws would not be used in this brutal violence but the law has proved ineffective and has not succeeded to achieve its aim of eliminating 'honor' killing. Despite the fact that the punishment according to anti-'honor' killing law is death or life imprisonment, it allows the judge to decide whether the committed murder was 'honor'-based or have another motive. For instance, in some reported cases of 'honor' killing in 2017, the accused claimed another motive of killing and heirs of victims forgave them under Qisas and Diyat law (Amnesty International, 2018) which is applicable to homicide except killing under the pretext of "honor". "honor"-based murders remained pervasive and intractable in 2017 even after the passing of the anti-'honor' bill. . The recent annual report of Human Rights Watch (2019) estimates that there are about 1,00o "honor" killings every year in Pakistan. One of the evils of the practice of 'honor' killing is that it has become a business since the notion of 'honor' is used as a cover for other killings. The inquiries of some reported incidents of 'honor' killings disclosed a trumped-up charge that hid the real causes behind these killings such as obtaining land, financial gains, property disputes, greed over the issue of inheritance, and family or tribal rivalry. Seeing the statistical data of the last two decades, nothing has changed, hundreds of women have been killed under the pretext of "honor" even after the change in legislation, which proved ineffective in halting this abhorrent practice that continue to escalate because perpetrators find it easier to evade punishment in this matter.

\section{The Reasons Behind the Occurrences of "honor" Killings}

The statistical figures of the "honor" killing incidents in Pakistan indicate that over the last two decades, nothing has changed in the frequency of the incidents even the new anti-'honor' law enacted. The main reasons behind the occurrence of "honor" killings in Pakistan are the following.

1) Patriarchal 'honor' codes, which organize interpersonal life and relations. The core 'honor' concerns can be derived from the 'honor' code that entails a group of values and norms defining 'honorable and dishonorable' behavior. The 'honor' code prescribes those things

\footnotetext{
${ }^{1}$ The Qisas and Diyat law places the choice of prosecution in the hands of the victims or their heirs and not in the hands of the government
} 
about which a person with a sense of 'honor' ought to be concerned. Any Pakistani who has a sense of 'honor' is more concerned with the issue of his reputation and fears of losing value and respect before others' eyes. His familial respect, social prestige and the notion of 'honor' determine his position and status in society; women of his family are perceived as the repository of family's 'honor'. Therefore, women being the repository of the family's 'honor' must behave in an honorable way by following the socially accepted and morally correct behavior. When an 'honor' code is believed to have been broken and perceived shame and disgrace is brought upon the family, men must punish them to prove their masculinity and restore the 'honor' of the family else they and their family may be labeled as 'dishonored family' families without 'honor'. The motive to commit such a crime is often the pressure of society

2) Gender-Biased Institutes and Legal Loopholes in Existing Laws

The efficient deterrence policy can deter people from committing an "honor" killing. The perpetrators know very well that, they may evade the punishment or get a minimum because of various factors including the corrupt and gender-biased police force, the weak judicial system, legal loopholes in existing laws, and tribal councils. Police system, the first contact with the criminal justice system in seeking justice, is corrupt, abusive, and genderbiased. The common practice of police force in cases of violence against women is very gender-biased and unprofessional. When any victim venture to report against violence encounter an inefficient and abusive police system which may turn away or harass the victim or may demand a bribe. Police come into action only in cases that are mediatized; else, they do not intervene to arrest the perpetrators. For instance, the cases of Mukhtara Mai and Qandeel Baloch receive media attention thereby forcing police to come into action and arrest the perpetrators. If these incidents were not mediatized, the police would probably have not taken action against the offenders and the cased would not have reached the courts for justice. Human Rights Watch conducted interviews from human rights lawyers and activists in 1999 revealed that virtually all interviewee reported that people who approach the police for seeking their service often encounter harassment, intimidation, physical abuse, and bribery due to lack of accountability in the gender-biased police force which is fraught with corruption and has no any gender sensitization training. Moreover, in many instances of 'honor' killing, the involvement of police officers has been reported. For example, how Deputy Superintendent of Police, in the case of murder in 2009 gave orders to the local authorities to hush up the case. Nothing has changed until today; interviews conducted two decades ago reflect the present picture of the police force in Pakistan. Many cases go unreported due to people's lack of confidence in the police and criminal justice system. In addition, before the promulgation of anti-'honor' law, the perpetrators of "honor" killing were often pardoned by the victims' families in accordance with the Qisas and Diyat law. Since 2016 anti-'honor' killing law has been enacted that mandates life imprisonment or the death penalty for convicted murderers, whose motive for killing was supposed restoration of 'honor' and strips families of the right to legally pardon the offenders, a practice that allowed the perpetrators to evade punishment under Qisas (retribution) and Diyat (blood money) laws. With the enactment of new laws, the accused have started to find other legal loopholes to evade punishment in this matter. For example, the accused of "honor" murder crimes can claim that the motives of their actions were other than the restoration of "honor" and heirs of victims can forgive them under Qisas and Diya laws, which is applicable in plain homicide. As a result, offenders have no fear of being apprehended by the police and being prosecuted in court.

In "honor" killings matters, usually the formal judicial system has been sidestepped on the grounds that the tribal system provides faster, cheaper and more lasting solution. Jirga system or decision-making assembly (tribal council), is among the major factor in maintaining "honor" killings in the country. Despite the fact that this tribal system of justice managed by local elites is banned by 
the government, it is actively practiced in Pakistan often with the support of law enforcement agencies and politicians. The man who murder to restore the "honor" is morally and legally supported by the Jirga (Bhanbhro, 2015) For example, a 15-member Jirga in Abbottabad ordered the killing of a minor girl for helping her friend escape the village to marry her free will. (HRCP, 2017). A young boy and girl are electrocuted by their own families on the orders of a tribal council, over a matter of "honor". (HRCP, 2018). Not only the Jirga system gives orders of killing in the name of 'honor' but also it gives verdicts in favor of perpetrators of 'honor' murderers. Two men who had confessed to killing their maternal uncle and their sister-in-law in a so-called 'honor' crime were acquitted based upon a Jirga verdict that was strongly condemned by the Human Rights Commission of Pakistan.

\section{Discussion and Conclusion}

'Honor' is the most cherished value in Pakistani patriarchal society. The ideology of 'honor' including gender inequality, gender oppression all are the manifestation of Patriarchy causing gender-based violence including "honor" killing. The prevailing ideologies of 'honor', a stimulus to 'honor' killing, Tribal councils, gender-biased, abusive, and corrupt to the core police force along with the weak judicial system and legal loopholes in existing laws are the determining factor of unabated incidents of killing under the pretext of 'honor'. In this kind of circumstance, where the ideology of 'honor' prevails and perpetrators know very well that, they may evade the punishment or get a minimum, they are more likely to kill women who are alleged to break the 'honor' code. Furthermore, the state apparatus itself is often responsible for giving protection to perpetrators involved in these crimes. The various organs of the state have systematically allowed violence to thrive and evolve in society.

Pakistan is bound by international laws like the Universal Declaration of Human Rights and the ICCPR. Pakistan also ratified the CEDAW the Declaration on the Elimination of Violence against Women, which states that:

States should condemn violence against women and should not invoke any custom, tradition or religious consideration to avoid their obligations with respect to its elimination. States should pursue by all appropriate means and without delay a policy of eliminating violence against women. (UN, 1993)

This study asserts that Murder is a crime against the state and cannot be settled by the citizens whatever their relationship with the deceased is. Settling the murder issues privately is the violation of international laws of which Pakistan is the ratified member. Furthermore, the gender bias permeates in institutions at all levels; Therefore, it is required that there must be mandatory sensitivity training for both the police investigating 'honor' crimes and the judges adjudicating over them. The authorities must ensure that police without bowing to any pressure be it political or religious impartially investigate the cases of 'honor' killings.

Parallel and informal justice system is a curse for Pakistani society, which functions under the hidden patronage of political, religious, and local landlords. This outdated and gender-biased justice system is erected on tribal culture and women enmity where the status of women is no more than an object that can be sold, bought, and exchanged. The parallel justice systems continue to harm women and girls by issuing unjust verdicts that undermine the rule of law. In most reported cases, the harshest punishments in the matter of 'honor' come from the outdated social structure. Therefore, the harsh and firm actions should be taken against those who manage and patronize tribal councils. In addition, the state must ensure that women, who report risk from their family, have access to safe emergency shelters and other services, especially protection

The incidents of "honor" killings are the manifestation of the patriarchal system and mindset. Prevention of violence and building emergency shelter for those who have been affected of violence are both critical elements but not sufficient to tackle the issue of "honor" killings in the country where almost overwhelming majority of school age girls are not currently studying in schools. The 
transformative change can only occur with the reduction of gender inequality and increasing gender equality. The state of women in Pakistan cannot be improved unless women get economic independence, greater access to education, increase participation in political activities, and get widespread awareness of socio-economic and political issues. The strengthening of the social, political, and economic position of women is the need of time to transform misogynistic society into a women-friendly society.

\section{References}

Amnesty International Report. (2018). Amnesty International Report 2017/18: The State of The World's Human Rights. Amnesty International 2018. Retrieved June 10, 2019, from https://www.amnesty.org/download/Documents/POL1067002018ENGLISH.PDF

Bhanbhro, S. (2015). Representation of Honour Killings: Critical Discourse Analysis of Pakistani English-Language Newspapers. In Sexuality, Oppression and Human Rights (pp. 1-16). Brill.

Amnesty International USA. (2012). Culture of Discrimination: A Fact Sheet on “honor"” Killings.

Daly, M., \& Wilson, M. (2017). Homicide: Foundations of human behavior. Routledge.

Fisk, R. (September, o7). Robert Fisk: The Crime Wave That Shames the World. The Independent. Retrieved June 5, 2019, from https://www.independent.co.uk/voices/commentators/fisk/robert-fisk-the-crimewave-thatshames-the-world-2072201.html

Gill, A. (2009). 'honor' killings and the quest for justice in black and minority ethnic communities in the United Kingdom. Criminal Justice Policy Review, 2o(4), 475-494.

Gill, A. K. (2014). Introduction:'Honour'and 'honour'-based violence: Challenging common assumptions. In 'Honour'Killing and Violence (pp. 1-23). Palgrave Macmillan, London.

Gilmore, D.D. (1987). 'honor' and shame and the unity of the Mediterranean. Washington, DC: American Anthropological Association.

Gilmore, D. D. (1990). Manhood in the making: Cultural concepts of masculinity. New Haven, CT: Yale University Press.

Gilmore, D.D., \& Gwynne, G. (1985) (Eds.). Sex and gender in Southern Europe. [Special Issue]. Anthropology, 9.

Goldstein, M. A. (2002). The biological roots of heat-of-passion crimes and 'honor' killings. Politics and the Life Sciences, 28-37.

Human Rights Commission of Pakistan. (2008). State of Human Rights in 2007. Human Rights Commission of Pakistan.

Human Rights Commission of Pakistan. (2010). State of Human Rights in 2009. Human Rights Commission of Pakistan.

Human Rights Commission of Pakistan. (2011). State of Human Rights in 2010. Human Rights Commission of Pakistan.

Human Rights Commission of Pakistan. (2014). State of Human Rights in 2013. Human Rights Commission of Pakistan.

Human Rights Commission of Pakistan. (2015). State of Human Rights in 2014. Human Rights Commission of Pakistan.

Human Rights Commission of Pakistan. (2017). State of Human Rights in 2016. Human Rights Commission of Pakistan.

Human Rights Commission of Pakistan. (2018). State of Human Rights in 2017. Human Rights Commission of Pakistan.

Human Rights Commission of Pakistan. (2019). State of Human Rights in 2018. Human Rights Commission of Pakistan.

Human Rights Watch. (2001). World Report 2001 Events of 200o. Human Rights Watch.

Human Rights Watch. (2009). World Report 2009 Events of 2008. Human Rights Watch.

Human Rights Watch. (2007). World Report 2007 Events of 2006. Human Rights Watch.

Human Rights Watch. (2019). World Report 2019 Events of 2018. Human Rights Watch.

Kordvani, A. H. (2002). Hegemonic masculinity, domination, and violence against women. Retrieved June 5, 2019, from http://citeseerx.ist.psu.edu/viewdoc/summary?doi=10.1.1.584.1434

Miller, W.I. (1993). Humiliation and Other Essays on Honour, Social Discomfort, And Violence. Ithaca, NY: Cornell University Press.

Mosquera, P. M. R., Manstead, A. S., \& Fischer, A. H. (2002). The role of honour concerns in emotional reactions to offences. Cognition \& Emotion, 16(1), 143-163. 
Nisbett, R.E., \& Cohen, D. (1996). Culture of Honour: The Psychology of Violence in the South. Boulder, CO: Westview.

Sharma, K. (2016) Understanding the concept of Honour Killing within the Social paradigm: Theoretical Perspectives. IOSR Journal Of Humanities And Social Science, Volume 21, Issue 9, Ver. 8, 26-32.

Shoro, S. (2019). The Real Stories behind Honour Killing. Cambridge Scholars Publishing.

Thomson Reuters Foundation Poll, (2018). The world's Most Dangerous Countries for Women 2018. Retrieved June 5, 2019, from https://poll2018.trust.org/

United Nations General Assembly. (1993). Declaration on the Elimination of Violence against Women. Retrieved June 5, 2019, from https://www.un.org/documents/ga/res/48/a48r104.htm

United Nations Population Fund, 2000. The state of the world's population 200o: Lives Together, Worlds Apart. Retrieved June 5, 2019, from https://www.unfpa.org/sites/default/files/pub-pdf/swp2ooo_eng.pdf

Wikan, U. (2008). In 'honor' of Fadime: Murder and shame. University of Chicago Press. 